\title{
Diel patterns of cell division in marine Synechococcus spp. (Cyanobacteria): use of the frequency of dividing cells technique to measure growth rate*
}

\author{
Lisa Campbell** \& Edward J. Carpenter \\ Marine Sciences Research Center, State University of New York at Stony Brook, Stony Brook, New York 11794, USA
}

\begin{abstract}
Natural populations of the planktonic cyanobacteria Synechococcus spp. exhibit a diel pattern in the frequency of dividing cells (FDC). Based on this observation, we tested the applicability of the FDC technique for estimating growth rate of a population grown on a light/dark cycle. In laboratory experiments, the phycoerythrin-containing strains WH7803, WH8012, WH8107, and WH8108 were grown under various light and temperature conditions and the duration of division, $t_{d}, a$ parameter necessary for the calculation of growth rate, was determined to be $3 \mathrm{~h}$. Using this $t_{d}$ value, growth rates of oceanic populations exhibiting diel patterns in FDC were found to range from 0.42 to $0.86 \mathrm{~d}^{-1}$, and these values exceed previous estimates of phytoplankton growth rates in oligotrophic regions. In experiments conducted at a Sargasso Sea station, growth rates calculated by the FDC technique were in close agreement with calculated instantaneous growth rates. In all cases, growth rates were higher for samples incubated at surface light intensities than at $1 \%$ surface light intensities. Using this technique under appropriate conditions, strain-specific growth rates can be determined.
\end{abstract}

\section{INTRODUCTION}

Cyanobacteria of the genus Synechococcus are a well-recognized component of the photosynthetic biomass in most regions of the world's oceans (Johnson \& Sieburth 1979, Waterbury et al. 1979, Glover 1985). Generally, estimates of the contribution by Synechococcus spp. to primary production are inferred from size-fractionation data. From such studies in several open ocean regions, the picoplankton fraction was found to be a major contributor to primary production (Li et al. 1983, Platt et al. 1983, Glover et al. 1985, 1986). When coccoid cyanobacteria are greater than $80 \%$ of the picoplankton biomass, the size-fractionation of ${ }^{14} \mathrm{C}$ bottle incubations may give a valid measure of Synechococcus production (Glover et al. 1986). In some cases, however, this method may not be feasible, such as in coastal regions, or when eukaryotic picoplankton (Johnson \& Sieburth 1982) are abundant.

\footnotetext{
- Contribution No. 524 from the Marine Sciences Research Center

- Present address: Department of Oceanography, University of Hawaii at Manoa, Honolulu, Hawaii 96822, USA
}

There is also concern that bottle incubations may lead to systematic errors in determining productivity such that production will be underestimated (Gieskes et al. 1979, Carpenter \& Lively 1980, Peterson 1980, Prézelin et al. 1986b).

The goal of this study was to develop a method based on direct cell counts to determine cell-specific estimates of Synechococcus growth. Direct counts of the increase in cell number is one means of obtaining a specific growth rate, but this rate most likely would be an underestimate because it would not account for grazing (Landry \& Hassett 1982). Heterotrophic nanoplankton (the presumed grazers of picoplankton) can be eliminated by prefiltration or by dilution of the sample with cell-free water to reduce grazing pressure. Both of these techniques have been employed successfully by some investigators to estimate microbial growth rates (Landry et al. 1984, Wright \& Coffin 1984), but with variable results (because of methods and/or assumptions of the models) by others (Ducklow \& Hill 1985). Recent evidence indicates that an increase in dissolved organics and amino acids may result from filtration of large volumes of sea water through Nucle- 
pore filters even under the gentlest filtration conditions (Furgeson et al. 1984, Fuhrman \& Bell 1985). Dilution techniques, or other preincubation manipulations, therefore, may alter available pools of nutrients and cause significant changes in microbial growth rates.

To avoid methods that require incubations or any experimental manipulations, the frequency of dividing cells (FDC) technique was used in this study. The FDC method for determination of microbial growth rates proposed by Hagström et al. (1979) is based upon the relation between the number of cells in a given stage of division and the growth rate, and it has been applied by many microbial ecologists (Newell \& Christian 1981, Hanson et al. 1983, Riemann \& Sondergaard 1984, Riemann et al. 1984). Phytoplankton ecologists have used a mitotic index derived for populations growing on light:dark cycles (Weiler \& Chisholm 1976 , Weiler \& Eppley 1979). Synechococcus populations were found to divide periodically (Waterbury 1984, this study), so the equation of McDuff \& Chisholm (1982), which was derived for a population grown under a light:dark cycle, was used to calculate the growth rate:

$$
\mu=\frac{1}{n t_{d}} \sum_{i=1}^{i=n} \ln \left(1+f_{i}\right)
$$

where $\mu=$ specific growth rate $\left(d^{-1}\right) ; f_{i}=$ fraction of dividing cells for a given sampling interval; $\mathrm{n}=$ number of sampling intervals; and $t_{d}=$ duration of cell division. Because Synechococcus spp. are prokaryotes, dividing cells are counted instead of dividing nuclei, as in the mitotic index (Weiler \& Chisholm 1976). To calculate growth rates from FDC data, 3 assumptions are made: (1) the duration of division $\left(t_{d}\right)$ is constant with respect to changing environmental conditions; (2) $t_{d}$ is identical for all cells in a population, and (3) all cells in a population are active. In this first investigation of the use of the FDC technique to measure growth rates of Synechococcus, we address the first of these assumptions.

The results reported here are observations of the diel patterns of cell divisions of Synechococcus spp. in culture and in natural populations. The duration of division was calculated in laboratory experiments and this value was used to estimate the growth rates of in situ populations of Synechococcus and the growth rates of incubated populations from time-course experiments.

\section{MATERIALS AND METHODS}

Strains. Two strains of marine phycoerythrin-dominant Synechococcus spp., WH7803 (Sargasso Sea isolate) and WH8107 (continental shelf isolate), from the collection of John Waterbury (Woods Hole Oceanographic Institution) were chosen for study because they are representative of different serogroups (Campbell 1985). For one experiment, 2 additional strains were used: WH8012, of similar size and of the same serogroup as WH7803; and WH8108, similar in size to WH8107 and also not of the WH7803 serogroup. Cultures were grown in polycarbonate flasks (Nalge) using f/2 medium (Guillard \& Ryther 1962) minus silica but with additional Vitamin $B_{12}\left(20 \mu \mathrm{gl}^{-1}\right)$.

Experimental growth conditions. To apply Equation (1) to determine specific division rates, it is necessary that $t_{d}$, the duration of cell division, be known and not vary with growth rate. For determination of $t_{d}$, strains were grown at each of 3 different temperatures $(15,20$, $25^{\circ} \mathrm{C}$ ), under 2 or 3 different light intensities, and on a 14:10 light:dark cycle. The light period began at 0600 h. The light source (cool white, General Electric) was screened to obtain low, medium, and high intensities $\left(6,21,55 \mu \mathrm{E} \mathrm{m} \mathrm{m}^{-2} \mathrm{~s}^{-1}\right.$, respectively). Growth of WH7803 was reported to be saturated at $45 \mu \mathrm{E} \mathrm{m} \mathrm{m}^{-2} \mathrm{~s}^{-1}$ (Morris \& Glover 1981); however, photosynthetic car-

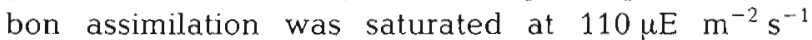
(Morris \& Glover 1981, Cuhel \& Waterbury 1984). Exponentially growing cultures were acclimated to each experimental condition for 2 to $3 \mathrm{~d}$. At $1000 \mathrm{~h}$ on Day 1 of an experiment, $10 \mathrm{ml}$ from the acclimated exponential-phase culture were inoculated into 2 replicate experimental flasks, each of which contained $90 \mathrm{ml}$ medium. Cell counts by epifluorescence were made at $1000 \mathrm{~h}$ each day to determine the specific growth rate $\left(d^{-1}\right)$. When the culture in the experimental flask again reached exponential growth (usually within 1 to $3 \mathrm{~d}$ ), samples were taken at $2 \mathrm{~h}$ intervals from each replicate flask, preserved with $5 \%$ buffered formalin, and stored protected from light at $4{ }^{\circ} \mathrm{C}$ until counted. Slides were prepared by filtering an aliquot of each sample onto a $0.4 \mu \mathrm{m}$ Nuclepore filter at $<100$ $\mathrm{mm} \mathrm{Hg}$. The FDC percentage $\left(\mathrm{f}_{\mathrm{i}}\right)$ was calculated from the number of dividing cells in a total count of 300 to 400 cells. A cell was considered dividing from when the cell wall began invagination until 2 visibly distinct cells could be identified. Using the sum of $\ln \left(1+\mathrm{f}_{i}\right)$ and the calculated specific growth rate, Equation (1) was solved for $t_{\mathrm{d}}$.

Field sampling. Experiments were conducted in 3 different oceanic regimes. In February 1984, on the R/V Atlantis II samples were collected from one Sargasso Sea station $\left(30^{\circ} 38^{\prime} \mathrm{N}, 76^{\circ} 14^{\prime} \mathrm{W}\right)$. During July and August 1984 on the R/ $V$ Cape Hatteras 3 stations in the Northwest Atlantic were occupied: 2 coastal stations, $\mathrm{P} 1$ and $\mathrm{P} 3\left(43^{\circ} 27^{\prime} \mathrm{N}, 68^{\circ} 36^{\prime} \mathrm{W}\right.$ and $42^{\circ} 30^{\prime} \mathrm{N}, 69^{\circ} 30^{\prime} \mathrm{W}$ [Wilkinson Basin], respectively), and a station within a warm core eddy (WCE), Station P2, (39 31' N, $66^{\circ} 20^{\prime} \mathrm{W}$ ). The WCE station was assumed to be rep- 
resentative of the Sargasso Sea (C. S. Yentsch pers. comm.). In March 1985 samples were collected from a blue water Caribbean site $10 \mathrm{~km}$ southwest of Puerto Rico $\left(17^{\circ} 45^{\prime} \mathrm{N}, 66^{\circ} 52^{\prime} \mathrm{W}\right)$.

For a $24 \mathrm{~h}$ period at each station, bucket samples were collected at 1 or $2 \mathrm{~h}$ intervals from the surface water to determine the diel pattern of cell division and to measure an in situ growth rate. A $100 \mathrm{ml}$ volume was fixed with buffered formalin ( $5 \%$ final concentration), and refrigerated until counted.

In addition, on-deck experiments were conducted during the Sargasso Sea and Northwest Atlantic cruises from which FDC counts were made. On the Sargasso Sea cruise in February 1984, samples were collected with acid-cleaned $(1.2 \mathrm{~N} \mathrm{HCl})$ Go-Flo bottles (General Oceanics) from the surface and the $1 \%$ light depth (estimated as $2.7 \times$ Secchi depth). Duplicate $750 \mathrm{ml}$ volumes in Whirlpak bags were incubated in on-deck incubators cooled with running surface sea water and either screened for $1 \%$ incident light, or not screened for surface light intensity. Time-course experiments began about an hour after dawn and continued for 12 to $24 \mathrm{~h}$. Two $50 \mathrm{ml}$ subsamples were removed at 4 or $6 \mathrm{~h}$ intervals and preserved with $5 \%$ buffered formalin.

On the Northwest Atlantic cruise in July-August 1984, samples were collected from the depth of maximum cell abundance (at the surface at the coastal station [P1]; at the chlorophyll maximum depth at the WCE station [P2]) and were incubated as above. All incubations began at dawn (except on July 22, when the experiment began at $2200 \mathrm{~h}$ ) and continued for 18 to $24 \mathrm{~h}$ with subsamples taken at $6 \mathrm{~h}$ intervals. For comparison, FDC data were also collected from several large volume experiments in which 2201 were incubated on board ship (Prézelin et al. 1986a). Water for these vat experiments was pumped from the sampling depth at $0300 \mathrm{~h}$ on the day of the experiment.
All preserved samples were refrigerated and protected from light until counted (within $2 \mathrm{wk}$ ). To count the sample, duplicate volumes were filtered onto stained (2\% Irgalan Black) $0.4 \mu \mathrm{m}$ Nuclepore filters and enumerated as described above for laboratory experiments.

Calculations. Specific growth rates $\left(\mathrm{d}^{-1}\right)$ from FDC data were calculated using Equation (1) and assuming $a t_{d}$ of $3 \mathrm{~h}(0.125 \mathrm{~d})$. The number of sampling intervals, $n$, varied among experiments. In situ growth rates at the Sargasso and Caribbean sites were calculated from hourly samples, so that $\mathrm{n}=24$. However, at the Northwest Atlantic stations samples were collected at $2 \mathrm{~h}$ intervals, so that $n=12$. For the incubation experiments, sampling intervals varied from $n=4$ for the Whirlpak incubations to $\mathrm{n}=12$ for the $220 \mathrm{l}$ vat experiments. For the few experiments of less than $24 \mathrm{~h}$ duration (i.e. lacking the early morning time points), the percentage of dividing cells for this interval was estimated from the in situ value at the corresponding hour; this percentage was always low (2 to $4 \%$ ).

Instantaneous growth rates, $\mathrm{k}\left(\mathrm{d}^{-1}\right)$, were calculated for the February 1984 Sargasso Sea experiments from:

$$
\mathrm{k}=\frac{1}{\mathrm{t}} \ln \frac{\mathrm{N}_{\mathrm{f}}}{\mathrm{N}_{\mathrm{o}}}
$$

where $\mathrm{N}_{0}=$ cell abundance at $\mathrm{t}=0$ (dawn); $\mathrm{N}_{\mathrm{f}}=$ cell abundance at the peak of division; $t=$ duration of growth experiment (h). To obtain a daily rate, this hourly rate was multiplied by the number of daylight hours (11 h).

\section{RESULTS}

The various conditions of light and temperature in laboratory experiments provided a range of specific growth rates from 0.10 to $1.02 \mathrm{~d}^{-1}$ (Table 1 ). The most rapid rates occurred at the highest temperature $\left(25^{\circ} \mathrm{C}\right)$

Table 1. Synechococcus spp. Specific growth rates $\left(\mathrm{d}^{-1}\right)$ of Strains WH7803, WH8107, WH8012, and WH8108 in laboratory experiments. $\mathrm{k}$ : specific growth rate $\left(\mathrm{d}^{-1}\right) ; \mathrm{r}^{2}$ : coefficient of determination for linear regression of daily cell counts

\begin{tabular}{|c|c|c|c|c|c|c|c|c|c|}
\hline \multirow{2}{*}{$\begin{array}{c}\text { Light } \\
\text { intensity } \\
\left(\mu \mathrm{E} \mathrm{m}^{-2} \mathrm{~s}^{-1}\right)\end{array}$} & \multicolumn{3}{|c|}{$15^{\circ} \mathrm{C}$} & \multicolumn{3}{|c|}{$20^{\circ} \mathrm{C}$} & \multicolumn{3}{|c|}{$25^{\circ} \mathrm{C}$} \\
\hline & Strain & $\mathrm{k}$ & $r^{2}$ & Strain & $k$ & $r^{2}$ & Strain & $\mathrm{k}$ & $r^{2}$ \\
\hline \multirow[t]{3}{*}{6} & WH7803 & 0.10 & 0.76 & WH7803 & 0.32 & 0.94 & WH7803 & 0.22 & 0.90 \\
\hline & WH8107 & No growth & & WH8107 & 0.25 & 0.91 & WH8012 & 0.47 & 0.99 \\
\hline & & & & & & & WH8107 & 0.29 & 0.93 \\
\hline \multirow[t]{3}{*}{21} & WH7803 & 0.25 & 0.95 & WH7803 & 0.44 & 0.96 & WH7803 & 0.44 & 0.92 \\
\hline & WH8107 & No growth & & WH8107 & 0.46 & 0.99 & WH8012 & 0.75 & 0.99 \\
\hline & & & & & & & WH8107 & 0.54 & 0.94 \\
\hline \multirow[t]{4}{*}{55} & & & & & & & WH7803 & 0.90 & 0.98 \\
\hline & & & & & & & WH8012 & 1.02 & 0.98 \\
\hline & & & & & & & WH8107 & 0.70 & 0.99 \\
\hline & & & & & & & WH8108 & 0.76 & 0.96 \\
\hline
\end{tabular}




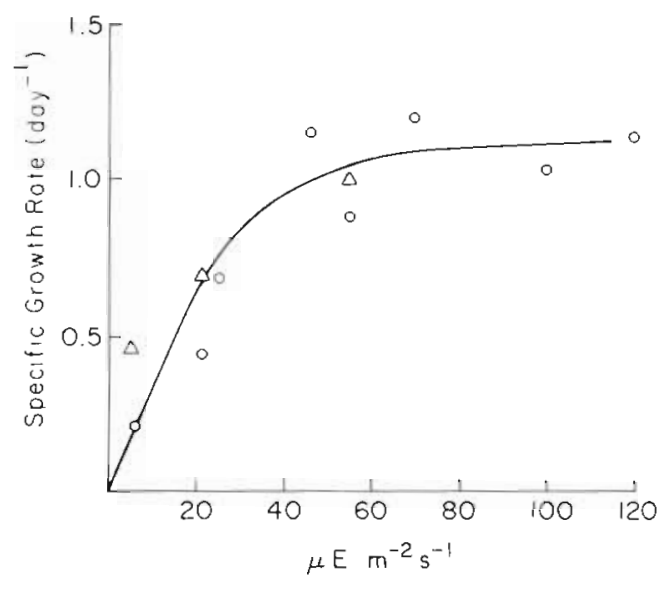

Fig. 1. Growth vs irradiance relation for Synechococcus strains of the 7803 seragroup. (O) WH7803; ( $\triangle$ ) WH8012

and light intensity $\left(55 \mu \mathrm{E} \mathrm{m}^{-2} \mathrm{~s}^{-1}\right)$. In an additional experiment with Strain WH7803, growth rates were measured at several higher light intensities to determine the light-saturated growth rate at $25^{\circ} \mathrm{C}$ (Fig. 1). Saturating light intensity for the WH7803 serogroup
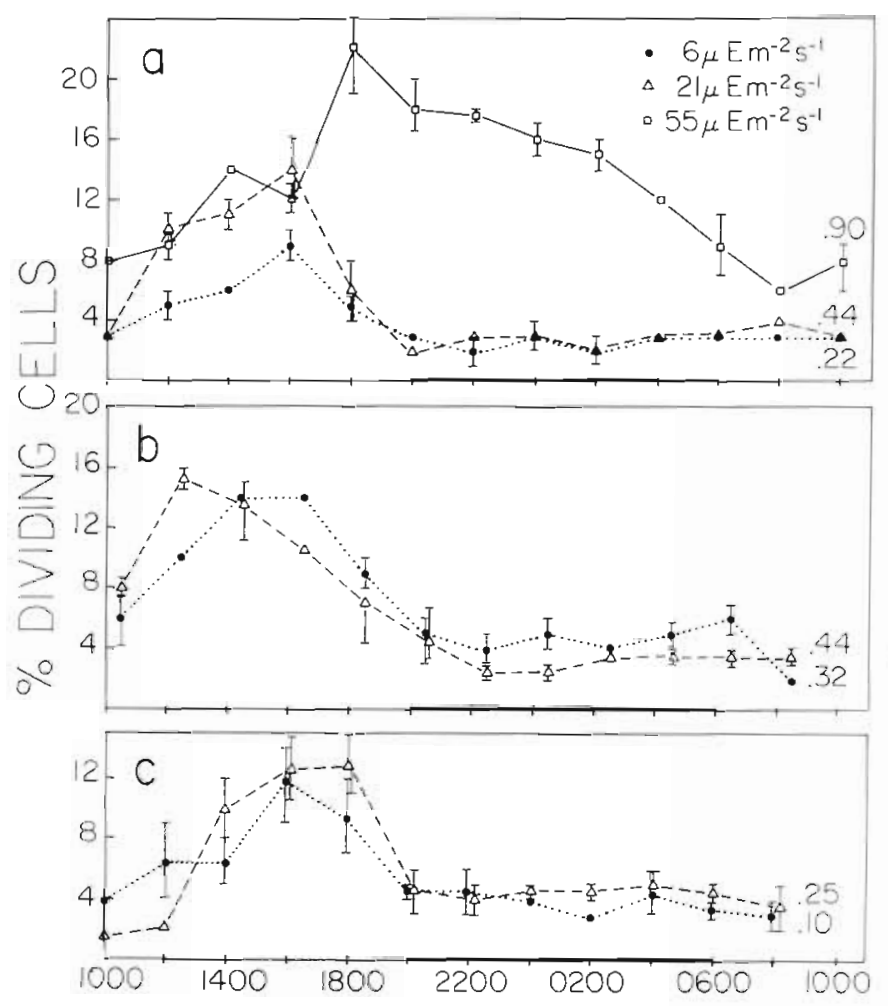

was calculated using the model from Gallegos \& Platt (1981), in which photoinhibition is ignored. The data were fit using the iterative curve fitting program of Caceci \& Cacheris (1984). (It was assumed that this photosynthesis model was appropriate for growth data.) The predicted saturating light intensity was $33 \mu \mathrm{E} \mathrm{m}^{-2} \mathrm{~s}^{-1}$, and the maximum specific growth rate was $1.11 \mathrm{~d}^{-1}$. The saturating light intensity observed here was lower than reported by Morris \& Glover (1981), but their rates were calculated from experiments conducted under constant illumination.

\section{Diel patterns of cell division in laboratory cultures}

Most cultures exhibited a diel pattern in the timing of cell division (Fig. 2 a to f). For Strain WH7803, the maximum number of dividing cells occurred between 10 and $12 \mathrm{~h}$ after the start of the light period (Fig. $2 \mathrm{a}$ to c), although the maximum occurred $2 \mathrm{~h}$ earlier in one

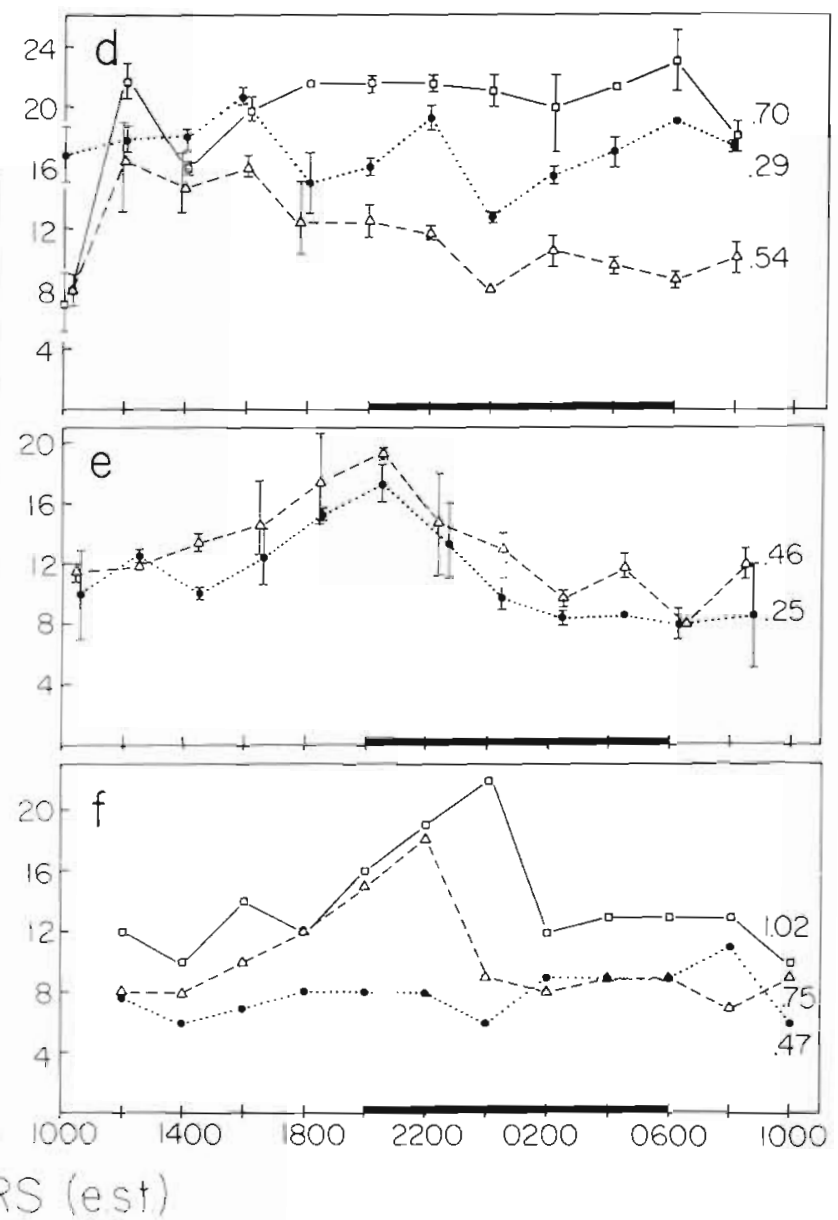

Fig. 2. Synechococcus spp. Diel patterns of frequency of dividing cells in cultures. For exponential phase laboratory cultures at 2 or 3 different light levels the diel pattern of the percentage of the population dividing is shown. Specific growth rates $\left(\mathrm{d}^{-1}\right)$ for each culture are shown on figure. (a) WH7803 at $25^{\circ} \mathrm{C}$; (b) WH7803 at $20^{\circ} \mathrm{C}$; (c) WH7803 at $15^{\circ} \mathrm{C}$; (d) WH8107 at $25^{\circ} \mathrm{C}_{i}$ (e) 
$20^{\circ} \mathrm{C}$ flask (Fig. 2b). The magnitude of the peak varied with the growth rate of the cultures. At the fastest growth rate $\left(0.90 \mathrm{~d}^{-1}\right.$, Fig. 2a), the maximum in the percentage of dividing cells was $22 \%$, but a large fraction of the cells were observed as dividing all day and after the light period ended. For slower growth rates, $<0.69 \mathrm{~d}^{-1}$ (equivalent to $<1$ division $\mathrm{d}^{-1}$ ), the periodicity of division was more pronounced, i.e. confined to a 2 to $4 \mathrm{~h}$ period, and the maximum percentage of dividing cells was correspondingly lower (Fig. $2 b, c)$.

Cultures of WH8107 also showed a pattern in the timing of cell division when grown at $20^{\circ} \mathrm{C}$, but the peak of division followed $14 \mathrm{~h}$ after the start of the light period. In contrast, at 21 and $55 \mu \mathrm{E} \mathrm{m}^{-2} \mathrm{~s}^{-1}$ light intensities at $25^{\circ} \mathrm{C}$, the percentage of dividing cells became fairly constant (Fig. 2d); this was true for WH8108 also (unpubl. data). The peak of division for Strain WH8012 (Fig. 2f) occurred later than the other strains (16 to $18 \mathrm{~h}$ after the light period began). Unlike the other strains at the higher specific growth rates $\left(0.75\right.$ and $\left.1.02 \mathrm{~d}^{-1}\right)$ the percentage of dividing WH8012 cells was not constant throughout the cycle and at the lowest light intensity a marked periodicity was not evident.

In summary, from our laboratory studies it was found that a diel pattern in cell division exists for Synechococcus spp. in most cases. The maximum percentage of dividing cells occurred from 8 to $18 \mathrm{~h}$ after the beginning of the light period, and the timing of this maximum varied among clones of Synechococcus. In general, for cultures at growth rates faster than $0.69 \mathrm{~d}^{-1}$ (equivalent to 1 division $\mathrm{d}^{-1}$ ), the maximum percentage of dividing cells was greater than $12 \%$ and the percentage remained high throughout much of the night. At growth rates less than 1 division $\mathrm{d}^{-1}$, the maximum in the frequency of dividing cells was confined to a shorter interval. The exception to this pattern was Strain WH8012, for which the percentage of dividing cells at $25^{\circ} \mathrm{C}$ was fairly constant at low growth rate only (Fig. 2f).

\section{Diel patterns of cell division in field populations}

In field populations, a diel pattern of cell division was also observed (Fig. 3a to c). At the tropical and subtropical stations (February 1984 Sargasso Sea station; July 1984 WCE station [P2]; and March 1985 Caribbean station), the highest percentage of dividing cells was observed just after sunset: 11 to $12 \mathrm{~h}$ after dawn in February 1984 and March 1985; and 15 to $18 \mathrm{~h}$ after dawn in July 1984. At the coastal stations in the Northwest Atlantic, there was no pronounced phased division, although at Station P1 a higher percentage (10 to $12 \%$ ) of dividing cells was observed from 1700

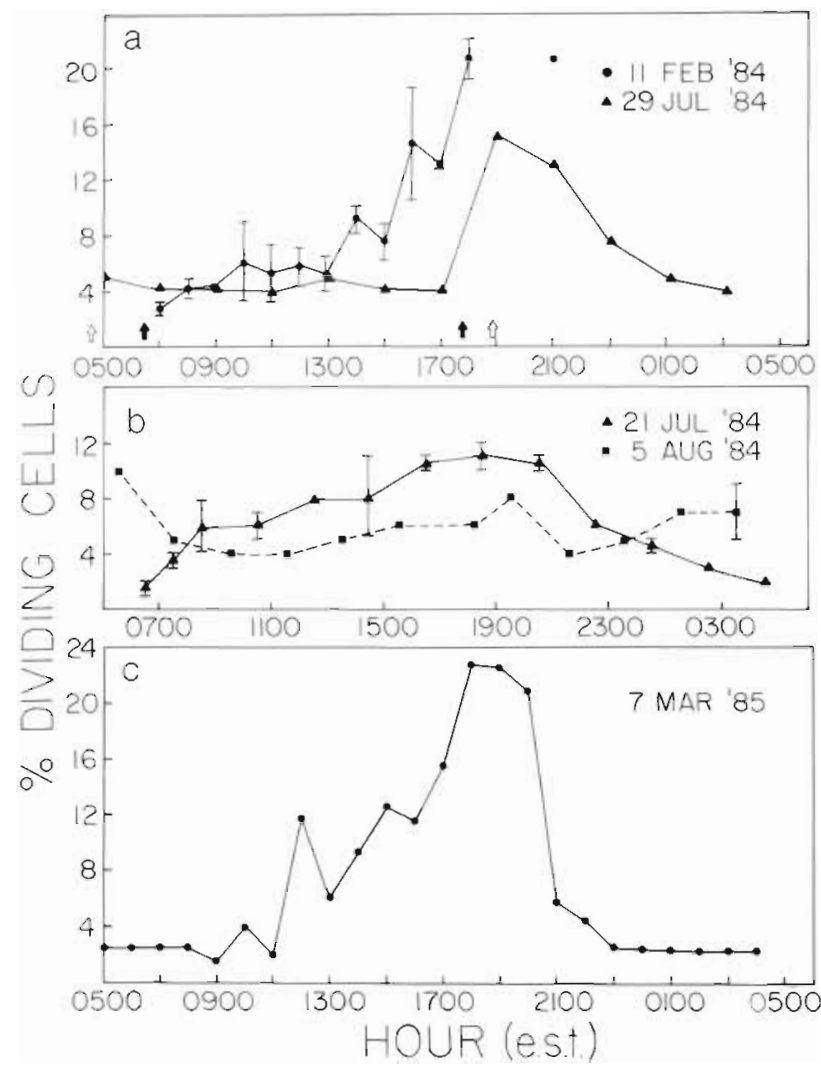

Fig. 3. Synechococcus spp. Diel patterns of dividing cells in field populations collected from the surface. (a) (†) Sargasso Sea, Feb 1984; (1) warm core eddy station (P2) in the Northwest Atlantic Ocean in Jul 1984; samples taken at $2 \mathrm{~h}$ intervals from surface water incubated in 220 l vats (Prézelin et al. 1986a). Closed arrows: time of dawn/dusk in Feb; open arrows: time of dawn/dusk in Jul. (b) Northwest Atlantic coastal stations, P1 ( $\mathbf{\Lambda}$ ), and P3 (a), in Jul and Aug 1984. (c) Caribbean station, $10 \mathrm{~km}$ southwest of Puerto Rico, Mar 1985

to $2200 \mathrm{~h}$. At the Wilkinson Basin site (P3), no sharp peak in the frequency of dividing cells was observed and the FDC ranged only from 4 to $9 \%$.

\section{Laboratory studies for determination of duration of division}

For Strains WH7803 and WH8012 the duration of division, $t_{d}$, was approximately $3 \mathrm{~h}$ at temperatures greater than $15^{\circ} \mathrm{C}$ and specific growth rates exceeding $0.4 \mathrm{~d}^{-1}$ (Fig. 4). Although $\mathrm{t}_{\mathrm{d}}$ was not constant under all conditions, for actively growing oceanic populations $3 \mathrm{~h}$ appears to be a reasonable estimate (see 'Discussion'), and this value was used in all subsequent calculations of growth rate for populations exhibiting a diel pattern of cell division. The accuracy of this $t_{d}$ value can be assessed only after additional observations and comparative experiments (e.g. Prézelin et al. 1986a). For Strains WH8107 and WH8108, the calculated $t_{d}$ 

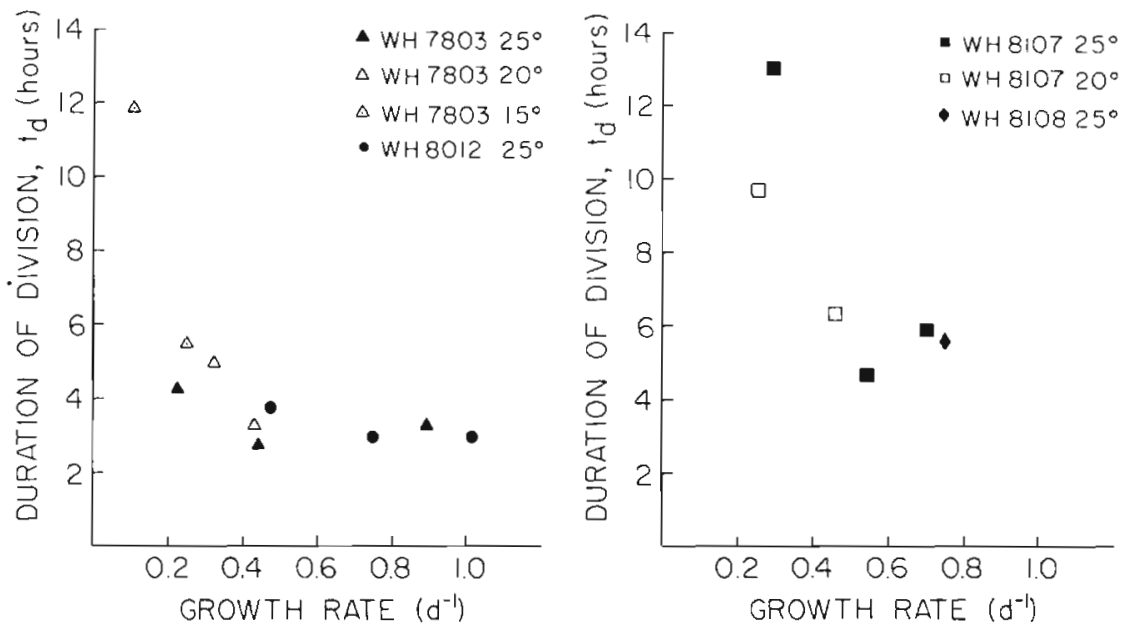

Fig. 4. Synechococcus spp. Duration of division, $t_{d}$ as a function of growth rate of laboratory-grown cultures. Left panel: 7803 serogroup. Right panel: WH8107 and WH8108

value was between 5 and $6 h$, and there was considerably more variation among these $t_{d}$ measurements than for the $t_{d}$ of the 7803-serogroup strains. Cells tended to form chains, rather than separate after division, so the percentage of dividing cells may have been overestimated, thus causing the estimate of $t_{d}$ to be too long.

\section{Growth rates of field populations by the FDC technique}

The in situ division patterns for most Synechococcus populations showed a strong diel pattern. Thus, we expected the populations were active and growth could be calculated using the FDC technique with a $t_{d}$ of $3 \mathrm{~h}$. Estimates of in situ growth rates for surface populations at all stations ranged from 0.45 to 0.73 (Table 2). The highest rate was observed at the Sargasso Sea station, February 1984 (Table 2). Hourly surface samples were counted, but the sampling was incomplete, so estimated FDC values for the 2200 to $0500 \mathrm{~h}$ interval were used. The in situ specific growth rate for surface populations at the Caribbean station

Table 2. Synechococcus spp, in situ growth rates. From hourly surface samples collected by bucket, growth rates were calculated from frequency of dividing cell data (using Eq. [1] and assuming $t_{d}=3 h$ ) at 3 oceanic sites: in the Sargasso Sea, 2 coastal stations in the Northwest Atlantic (P1 and P3), and the Caribbean

\begin{tabular}{|llcc|}
\hline Date & \multicolumn{1}{c}{ Location } & $\begin{array}{c}\text { Temp } \\
\left({ }^{\circ} \mathrm{C}\right)\end{array}$ & $\begin{array}{c}\text { Specific } \\
\text { growth rate } \\
\left(\mathrm{d}^{-1}\right)\end{array}$ \\
\hline Feb 84 & Sargasso Sea & 22 & 0.73 \\
Jul 84 & Gulf of Maine, P1 & 15 & 0.53 \\
Aug 84 & Wilkinson's Basin, P3 & 20 & 0.45 \\
Mar 85 & Caribbean Sea & 26 & 0.56 \\
\hline
\end{tabular}

(March 1985) was $0.56 \mathrm{~d}^{-1}$ (Table 2). Again, this calculation was based on hourly counts for 0900 to $2300 \mathrm{~h}$, but counts $(2.5 \%)$ for the 2400 to $0800 \mathrm{~h}$ were estimated (Fig. 3c). At the Northwest Atlantic coastal stations (P1 and P3), the in situ growth rates for surface Synechococcus populations (Fig. 3b) were slower than at the Sargasso station (Table 2). Our estimated $t_{d}$ may not be accurate at Station P1 because of the cold water temperature and the absence of the 7803-serogroup (Glover et al. 1986). In situ data were not available from the WCE (P2) station.

In the on-deck incubation experiments conducted during the February 1984 Sargasso Sea cruise, specific growth rates based on FDC counts, assuming a $t_{d}$ of $3 \mathrm{~h}$, varied from 0.15 to $0.82 \mathrm{~d}^{-1}$ (Table 3 ). A strong correlation was observed between growth rates calculated from FDC data and instantaneous growth rates calculated from cell counts of the same samples using Equation (2) $(r=0.81 ; p<0.01, d F=13)$ (Fig. 5). The line drawn in Fig. 5 shows a hypothetical 1:1 correlation. Almost all FDC estimates were higher than the instantaneous growth rates because the latter estimates did not account for grazing. Growth rates were highest in samples incubated at surface light intensity $\left(I_{0}\right)$ (Table 3 ). On average, rates at $1 \% I_{0}$ were only 30 to $40 \%$ of the rates measured at surface intensities. Also, the growth rates were higher on sunny days (9 to 13 February) than on stormy days $(5$ to 7 February) (Table 3). The water column was very well mixed, so that cells were distributed evenly in the upper $80 \mathrm{~m}\left(10\right.$ to $25 \times 10^{6}$ cells $\left.\mathrm{I}^{-1}\right)$ and temperature was $22^{\circ} \mathrm{C}$.

At all 3 Northwest Atlantic stations, on-board experiments were conducted to estimate growth rate by the FDC technique (Table 4). At both coastal stations, P1 and P3, the growth rates for a surface sample incubated at $80 \% \mathrm{I}_{0}$ were in fairly close agreement with the in situ surface growth rates $( \pm 4 \%$ ), but a wider discre- 
Table 3. Synechococcus spp. growth rates at a Sargasso Sea station, 30 $38^{\prime} \mathrm{N}, 76^{\circ} 14^{\prime} \mathrm{W}$, Feb 1984. Specific growth rates (d ${ }^{-1}$ ) were determined by the frequency of dividing cells (FDC) technique using Eq. (1) and assuming $t_{d}=3 \mathrm{~h}$. Time-course experiments began just after dawn and FDC counts were made at intervals during the incubation $(n=4)$. Reported rates are the mean of duplicates; variation between duplicates was $<10 \%$ in most cases

\begin{tabular}{|c|c|c|c|c|}
\hline Depth of sample collection & Date (1984) & Temp $\left({ }^{\circ} \mathrm{C}\right)$ & \multicolumn{2}{|c|}{ Growth rates at different incubation light conditions $\left(\mathrm{d}^{-1}\right.$} \\
\hline Surface & 5 Feb & 22 & 0.42 & ND \\
\hline Surface & 6 Feb $^{\circ}$ & 22 & 0.42 & 0.15 \\
\hline Surface & 9 Feb & 22 & 0.62 & ND \\
\hline Surface & 13 Feb & 22 & 0.63 & 0.46 \\
\hline $81 \mathrm{~m}$ & $5 \mathrm{Feb}^{*}$ & 22 & ND & 0.41 \\
\hline $42 \mathrm{~m}$ & 7 Feb & 22 & 0.56 & 0.26 \\
\hline $81 \mathrm{~m}$ & 9 Feb & 22 & 0.82 & ND \\
\hline $51 \mathrm{~m}$ & 10 Feb & 22 & 0.75 & 0.16 \\
\hline $81 \mathrm{~m}$ & 12 Feb & 22 & 0.62 & 0.16 \\
\hline $\begin{array}{l}\text { - Cloudy, stormy days } \\
\text { ND: no data }\end{array}$ & & & & \\
\hline
\end{tabular}

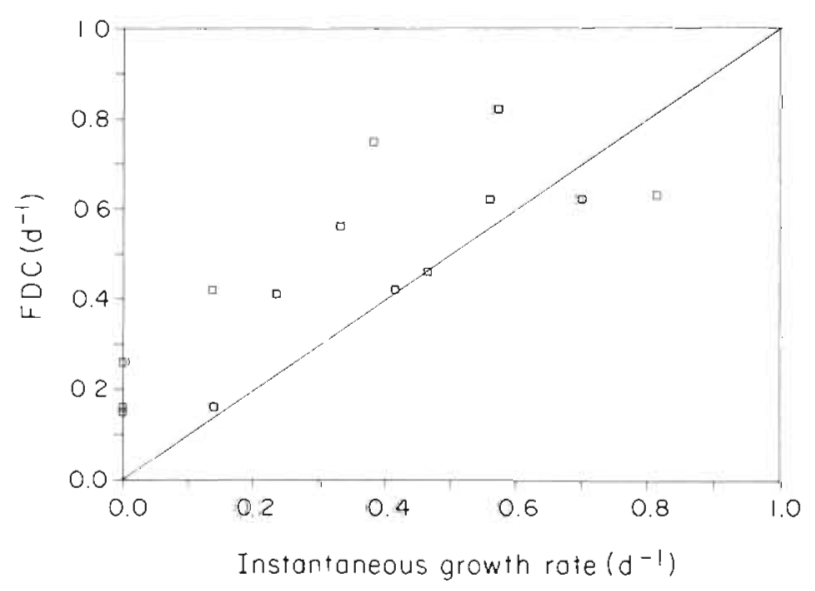

Fig. 5. Synechococcus spp. Comparison of growth rate estimates at a Sargasso Sea station in Feb 1984. Significant correlation $(p<0.05)$ was found between growth rates $\left(\alpha^{-1}\right)$ measured by the frequency of dividing cells (FDC) technique and the instantaneous daily growth rate calculated from cell counts for the same samples using Eq. (2). Solid line is a predicted 1:1 relation; most data points are above this line, which indicates the FDC estimates are higher than the instantaneous rates, where grazing is not accounted for in the experiment pancy between estimates was noted at the Wilkinson's Basin station (P3). Again, as in February 1984, at the Sargasso Sea station (P2) the growth rates were higher for the samples incubated at surface light intensities $\left(80 \% \mathrm{I}_{0}\right)$ than those incubated at $1 \% \mathrm{I}_{0}$ (Table 4). The surface light intensity at Stations P2 and P3 was $925 \mu \mathrm{E}$ $\mathrm{m}^{-2} \mathrm{~s}^{-1}$ (C. S. Yentsch pers. comm.). From Fig. 1, the predicted growth rate at $9.25 \mu \mathrm{E} \mathrm{m}^{-2} \mathrm{~s}^{-1}$ (the $1 \%$ light level) would be approximately $28 \%$ of the maximum predicted growth rate. This agrees closely with our observations in the Sargasso Sea, where growth rates at the $1 \%$ light level were approximately $25 \%$ of the surface growth rate. Light data were not available for other stations. Growth rate estimates from incubated samples at the WCE station were within the same range as our growth estimates for the Sargasso and Caribbean Seas (Table 2). In all cases, growth rates were higher for populations incubated at surface intensities. The measured specific growth rates ranged from 0.42 to $0.86 \mathrm{~d}^{-1}$, which is 38 to $77 \%$ of the maximal rate measured in the laboratory for the 7803 serogroup (Fig. 1).

Table 4. Estimates of Synechococcus spp. specific growth rates $\left(\mathrm{d}^{-1}\right)$ from samples incubated on board ship in either $750 \mathrm{ml}$ volumes (where $n=4$ ) or $220 \mathrm{l}$ vat experiments (where $n=12$; Prézelin et al. 1986a) at 3 stations in the Northwest Atlantic: P1, a coastal Gulf of Maine station $\left(43^{\circ} 27^{\prime} \mathrm{N}, 68^{\circ} 37^{\prime} \mathrm{W}\right)$; P2, in a warm-core eddy $\left(39^{\circ} 31^{\prime} \mathrm{N}, 66^{\circ} 20^{\prime} \mathrm{W}\right)$; and P3, Wilkinsons Basin, $\left(42^{\circ} 30^{\prime} \mathrm{N}, 69^{\circ} 30^{\prime}\right)$

\begin{tabular}{|ccccccc|}
\hline Station & $\begin{array}{c}\text { Date } \\
(1984)\end{array}$ & $\begin{array}{c}\text { Temp } \\
\left({ }^{\circ} \mathrm{C}\right)\end{array}$ & $\begin{array}{c}\text { Sample } \\
\text { source } \\
(\mathrm{m})\end{array}$ & $\begin{array}{c}\text { No. of } \\
\text { samples } \\
(\mathrm{n})\end{array}$ & $\begin{array}{c}\text { Specific growth rates at different incubation } \\
\text { light intensities }\left(\mathrm{d}^{-1}\right) \\
5 \% \mathrm{I}_{0}\end{array}$ \\
\hline $\mathrm{P} 1$ & $22 \mathrm{Jul}$ & 15 & Surface & 4 & 0.54 & - \\
$\mathrm{P} 2$ & $29 \mathrm{Jul}$ & 25 & Surface & 12 & 0.58 & - \\
$\mathrm{P} 2$ & $26 \mathrm{Jul}$ & 22 & 30 & 4 & 0.63 & - \\
$\mathrm{P} 2$ & $29 \mathrm{Jul}$ & 22 & 36 & 4 & 0.86 & - \\
$\mathrm{P} 3$ & $5 \mathrm{Aug}$ & 21 & Surface & 12 & 0.59 & - \\
\hline
\end{tabular}




\section{DISCUSSION}

The observed diel pattern of cell division in cultures of PE-containing Synechococcus spp. is similar to patterns observed for synchronous eukaryotic algae (Weiler \& Eppley 1979, Chisholm 1981, Edmunds \& Adams 1981). The timing of the peak of dividing cells observed in our cultures (Fig. $2 a$ to c) is similar to the pattern of cell division rates reported by Lorenzen (cited in Chisholm 1981), who found that the cell division rate increased during the light period, reached a maximum at the end, and declined during the dark. These patterns appear to be consistent with the photosynthetic activity of Synechococcus Strain WH7803, in which photosynthesis ceases when the culture is removed from the light (Waterbury unpubl.). At growth rates greater than 1 division $\mathrm{d}^{-1}$, the percentage of dividing cells remained high for a longer interval. When growth was saturated, for example, in the case of WH8107 at $25^{\circ} \mathrm{C}$ (unpubl. data), cells no longer exhibited phased division (Fig. 2d). This lack of periodicity was also observed for Euglena gracilis when growth rates were greater than 1 division $\mathrm{d}^{-1}$ (Edmunds \& Adams 1981).

The accuracy of the FDC technique for measuring growth rate depends on 3 assumptions: (1) the duration of division, $t_{d}$ is constant under varying conditions; (2) $t_{d}$ is identical for all cells in a population; and (3) all cells in a population are active. In our experiments to investigate the constancy of $t_{d}$, this assumption holds at temperatures above $15^{\circ} \mathrm{C}$ and at specific growth rates greater than $0.4 \mathrm{~d}^{-1}$ (Fig. 4). The results for the 2 Sargasso strains WH7803 and WH8012 did not vary significantly, thus $3 \mathrm{~h}$ appears to be a reasonable estimate of $t_{d}$ for this serogroup. The WH8107 cells which we observed remaining together as chains exhibited a condition which is rarely, if ever, seen in natural populations of PE-Synechococcus. Thus, the chains may have been an artifact of the culture conditions, which would have caused the 5 to $6 \mathrm{~h}$ estimate of $t_{d}$ to be incorrect. Additional data are necessary to determine if $t_{d}$ is the same for all Synechococcus clones. If $t_{d}$ does vary among Synechococcus clones, then the species composition of the population should be determined before using the FDC technique. At our field stations, the 7803 serogroup was present at the WCE and Caribbean sites, but was absent at the Northwest Atlantic coastal stations. The time at which the peak of division occurs may also vary among clones (Fig. $2 a$ to f), and although this does not affect the calculation of growth rate, it should be known when designing sampling intervals for in situ studies.

The other assumptions were not tested directly in our experiments. Other investigators have shown that the duration of division in light-limited cultures of Anacystis nidulans did vary among cells in a population because the division cycle appeared to arrest during the dark penod (Herdman et al. 1970). The results of Waterbury (unpubl.) suggest a similar pattern may exist in the marine Synechococcus WH7803. Our results for light-limited cultures of WH7803 at growth rates less than 1 division $\mathrm{d}^{-1}$ show that the percentage of dividing cells falls to approximately $4 \%$ in the dark period following the peak in division (Fig. $2 \mathrm{a}$ to c). This suggests that most cells of the populations are completing division. Under conditions other than those of our experiment, however, a different pattern might be observed. Factors other than growth rate (such a nutrient conditions) are known to affect the division pattern of diatoms (Chisholm \& Costello 1980), and may influence the division pattern of Synechococcus spp. (Prézelin et al. 1986a).

Lastly, all cells of a population must be metabolically active; otherwise growth rate will be underestimated by the FDC technique. Because only Synechococcus cells are counted, this is probably not as serious a problem as when estimating the growth rate for the microbial community as a whole using FDC data from direct counts by the acridine orange technique. To test this assumption in future experiments, however, autoradiography can be used to assess the percentage of metabolically active cells (Riemann et al. 1984). Alternatively, FDC counts can be made from immunofluorescently labelled cells (Campbell et al 1983) to estimate strain-specific growth rates and to observe any differences in growth rates among strains. The effect of grazing may also cause the FDC-based growth rate to be underestimated. If the grazing pressure on dividing cells is greater (because they are physically bigger), then the fraction of dividing cells would be underestimated.

Given the uncertainties, the FDC technique cannot be applied in all cases. However, in oceanic regions where water temperature is greater than $15^{\circ} \mathrm{C}$, where populations exhibit a strong diel periodicity in division, and the percentage of dividing cells is low overnight, the FDC approach can provide a reasonable estimate of growth rate for natural populations of Synechococcus spp. Our observed growth rates in some cases approached the maximal growth rates measured in the laboratory. The growth rates for Synechococcus spp. estimated in this study (approximately 1 division $\mathrm{d}^{-1}$ ) are several times faster than previous estimates for phytoplankton in oligotrophic regions (0.2 divisions $\mathrm{d}^{-1}$; Eppley 1980) and a previous estimate of Synechococcus growth rate $(0.2$ division $\mathrm{d}^{-1}$; Platt et al. 1983). Because cyanobacteria are a large component of the biomass in oligotrophic regions of the ocean, our results lend increased support to the concept of a dynamic open-ocean phytoplankton community (Goldman et al. 1979, Goldman 1980). 
It is also interesting to note that, in most cases, growth rates were higher for samples incubated at surface light intensities than at $1 \% \mathrm{I}_{0}$ light levels. Results from concurrent experiments on the Northwest Atlantic cruise in July-August 1984, indicated that the Synechococcus populations collected at the surface were not photoinhibited (Prézelin et al. 1986b). Thus, although these organisms are capable of photosynthesis at very low light levels, maximal growth rates may be realized at higher light levels. Maximum cell abundance at the Wilkinson Basin station occurred at $18 \% \mathrm{I}_{0}(15 \mathrm{~m})$, which was coincident with the depth of the maximum in situ primary productivity (Glover et al. 1986). For analogous populations in freshwater systems, similar photosynthetic responses have been observed. Ultraplankton dominates at the base of the euphotic zone and at aphotic depths in Lake Tahoe (Paerl et al. 1976, Vincent \& Goldman 1980). Although this population, which includes cyanobacteria, is adapted to extremely low light levels, it is able to photosynthesize at surface light intensities (Tilzer et al. 1977). It will be interesting to observe the variation of Synechococcus spp. growth rates with depth in the water column using the FDC technique, and to determine how growth rate varies with respect to in situ light levels.

By using the FDC technique, the artifacts which hinder traditional growth rate measurements (selective grazing, nutrient depletion, toxicity, unknown bottle effects) can be avoided because the sample is not incubated. Other advantages of this method are: (1) individual cyanobacteria can be recognized easily by epifluorescence microscopy and cell division is quite obvious; (2) counts can be made from preserved material so immediate observation is not necessary; and (3) estimates are specific for Synechococcus. Thus, when applied in appropriate conditions, the FDC technique can provide a species-specific growth rate measurement.

Acknowledgements. We thank Drs. R. Flood, B. Prézelin, H. Glover, and J. Corredor for aid in sampling and allowing us to participate on cruises. We thank A. Matlick for data analysis and S. Dunham for technical assistance. We acknowledge the helpful comments of Dr. S. W. Chisholm during the preparation of this manuscript. This study was funded by NSF grant \#OCE 8214764 to E.J.C.

\section{LITERATURE CITED}

Caceci, M. S., Cacheris, W. P. (1984). Fitting curves to data Byte 9 (5): $340-362$

Campbell, L. (1985). Investigations of marine, phycoerythrincontaining Synechococcus spp. (Cyanobacteria): distribution of serogroups and growth rate measurements. Ph. D. dissertation, State Univ. of New York, Stony Brook
Campbell, L., Carpenter, E. J., Iacono, V. J. (1983). Identification and enumeration of marine chroococcoid cyanobacteria by immunofluorescence. Appl. environ. Microbiol. 46: 553-559

Carpenter, E. J., Lively, J. S. (1980). Review of estimates of algal growth using ${ }^{14} \mathrm{C}$ techniques. In: Falkowski, P. G. (ed.) Primary productivity in the sea. Plenum Publ. Corp., New York, p. 161-478

Chisholm, S. W. (1981). Temporal patterns of cell division in unicellular aglae. In: Platt, T (ed.) Physiological bases of phytoplankton ecology. Can. Bull. Fish. Aquat. Sci. 210: 150-181

Chisholm, S. W., Costello, J. C. (1980). Influence of environmental factors and population composition on the timing of cell division in Thalassiosira fluviatilis (Bacilliophyceae) grown on light/dark cycles. J. Phycol. 16: 375-383

Cuhel, R. L., Waterbury, J. B. (1984). Biochemical composition and short-term nutrient incorporation patterns in a unicellular marine cyanobacterium, Synechococcus (WH 7803). Limnol. Oceanogr. 29: 370-374

Ducklow, H. W., Hill, S. M. (1985). The growth of heterotrophic bacteria in the surface waters of warm core rings. Limnol. Oceanogr. 30: 239-259

Edmunds, L. N., Jr., Adams, K. J. (1981). Clocked cell cycle clocks. Science 211: 1002-1013

Eppley, R. E. (1980). Estimating phytoplankton growth rates in the central oligotrophic oceans. In: Falkowski, P. G. (ed.) Primary productivity in the sea. Plenum Publ. Corp., New York, p. 231-242

Fuhrman, J. A., Bell, T. M. (1985). Biological considerations in the measurement of disolved free amino acids in seawater and implications for chemical and microbiological studies. Mar. Ecol. Prog. Ser. 25: 13-21

Furgeson, R. L., Buckley, E. N., Palumbo, A. V. (1984). Response of marine bacterioplankton to differential filtration and confinement. Appl. environ. Microbiol. 47: 49-55

Gallegos, C. L., Platt, T. (1981). Photosynthesis measurements on natural populations of phytoplankton: numerical analysis. In: Platt, T. (ed.) Physiological bases of phytoplankton ecology. Can. Bull. Fish. Aquat. Sci. 210 : $103-112$

Gieskes, W. W. C., Kraay, G. W., Baars, M. A. (1979). Current ${ }^{14} \mathrm{C}$ methods for measuring primary production: gross underestimates in oceanic waters. Neth. J. Sea Res. 13: $58-78$

Glover, H. E. (1985). The physiology and ecology of the marine cyanobacterial genus Synechococcus. In: Jannasch, H. W., Williams, P. J. leB. (ed.) Advances in aquatic microbiology. Academic Press, New York, 3: 49-107

Glover, H. E., Campbell, L., Prézelin, B. B. (1986). Contribution of Synechococcus spp. to size-fractioned primary productivity in three water masses in the Northwest Atlantic. Mar. Biol. 91: 193-203

Glover, H. E., Phinney, D. A., Yentsch, C. S. (1985). Photosynthetic characteristics of picoplankton compared with those of larger phytoplankton populations, in various water masses in the Gulf of Maine. Biol. Oceanogr. 3: 223-248

Goldman, J. C. (1980). Physiological processes, nutrient availability, and the concept of relative growth rate in marine phytoplankton ecology. In: Falkowski, P. G. (ed.) Primary productivity in the sea. Plenum Publ. Corp., New York, p. 179-192

Goldman, J. C., McCarthy, J. J., Peavey, D. G. (1979). Growth rate influence on the chemical composition of phytoplankton in oceanic waters. Nature, Lond. 279: 210-215 
Guillard, R. R. L., Ryther, J. H. (1962). Studies of marine planktonic diatoms. I. Cyclotella nana Hustedt, and Detonula confervacea (Cleve) Gran. Can. J. Microbiol. 8: 229-239

Hagström, A., Larsson, U., Horstedt, P., Normark, S. (1979). Frequency of dividing cells, a new approach to the determination of bacterial growth rates in aquatic environments. Appl. environ. Microbiol. 37: 805-812

Hanson, R, R., Shafer, D., Ryan, T., Pope, D. H., Lowery, H. K. (1983). Bacterioplankton in Antarctic Ocean waters during late austral winter: abundance, frequency of dividing cells, and estimates of production. Appl. environ. Microbiol. 45: 1622-1632

Herdman, M., Faulkner, B. M., Carr, N. G. (1970). Synchronous growth and genome replication in the blue-green alga, Anacystis nidulans. Arch. Mikrobiol. 73: 238-249

Johnson, P. W., Sieburth, J. MCN. (1979). Chroococcoid cyanobacteria in the sea: a ubiquitous and diverse phototrophic biomass. Limnol. Oceanogr. 24: 928-935

Johnson, P. W., Sieburth, J. McN. (1982). In situ morphology and occurrence of eukaryotic phototrophs of bacterial size in the picoplankton of estuarine and oceanic waters. J. Phycol. 18: 318-327

Landry, M. R., Hassett, R. P. (1982). Estimating the grazing impact of marine micro-zooplankton. Mar. Biol. 67 283-288

Landry, M. R., Haas, L. W., Fagerness, V. L. (1984). Dynamics of microbial plankton communities: experiments in Kaneohe Bay, Hawaii. Mar. Ecol. Prog. Ser. 16: 127-133

Li, W. K. W., Subba Rao, D. V., Harrison, W. G., Smith, J. C., Cullen, J. J., Irwin, B., Platt, T. (1983). Autotrophic picoplankton in the tropical ocean. Science 219: 292-295

McDuff, R. E., Chisholm, S. W. (1982). The calculation of in situ growth rates of phytoplankton populations from fractions of cells undergoing mitosis: a clarification. Limnol. Oceanogr. 27: 783-788

Morris, I., Glover, H. E. (1981). Physiology of photosynthesis by marine coccoid cyanobacteria - some ecological implications. Limnol. Oceanogr. 26: 957-961

Newell, S. Y., Christian, R. R. (1981). Frequency of dividing cells as an estimator of bacterial productivity. Appl. environ. Microbiol. 42: 23-31

Paerl, H. W., Tilzer, M. M., Goldman, C. R. (1976). Chlorophyll a versus adenosine triphosphate as algal biomass indicators in lakes. J. Phycol. 12: 242-246

Peterson, B. $(1980)$. Aquatic primary productivity and the ${ }^{14} \mathrm{CO}-\mathrm{CO}_{2}$ method: a history of the productivity problem. Ann. Rev. Ecol. Syst. 11:359-385
Platt, T. Subba Rao, D. V., Irwin, B. (1983). Photosynthesis of picoplankton in the oligotrophic ocean. Nature, Lond. 301: $702-704$

Prézelin, B. B., Glover, H. E., Campbell, L. (1986a). Photonutritive effects on growth rate estimates and diel patterns of cellular metabolism in natural populations of Synechococcus spp. Mar. Biol. (in press)

Prézelin, B. B., Putt, M., Glover, H. E. (1986b). Diurnal patterns in photosynthetic capacity and depth-dependent photosynthesis-irradiance relationships in Synechococcus spp. and larger phytoplankters in three water masses Mar. Biol. 91: 205-217

Riemann, B., Sondergaard, M. (1984). Measurements of diel rates of bacterial secondary production in aquatic environments. Appl. environ. Microbiol. 47: 632-638

Riemann, B., Nielsen, P., Jeppesen, M., Marcussen, B., Fuhrman, J. A. (1984). Diel changes in bacterial biomass and growth rates in coastal environments, determined by means of thymidine incorporation into DNA, frequency of dividing cells $(F D C)$, and microautoradiography. Mar. Ecol. Prog. Ser. 17: 227-235

Tilzer, M. M., Paerl, H. W., Goldman, C. R. (1977). Sustained viability of aphotic phytoplankton in Lake Tahoe (California-Nevada). Limnol. Oceanogr. 22: 84-91

Vincent, W. F., Goldman, C. R. (1980). Evidence for algal heterotrophy in Lake Tahoe, California-Nevada. Limnol. Oceanogr. 25: 89-99

Waterbury, J. B. (1984). In situ diel rhythms of marine Synechococcus. EOS (Trans. Am. geophys. Un.) 65 (45): 896

Waterbury, J. B., Watson, S. W., Guillard, R. R. L., Brand, L (1979). Widespread occurrence of a unicellular, marine, planktonic cyanobacterium. Nature, Lond. 227: 293-294

Weiler, C. S., Chisholm, S. W (1976). Phased cell division in natural populations of marine dinoflagellates from shipboard cultures. J. exp. mar. Biol. Ecol. 25: 239-247

Weiler, C. S., Eppley, R. E. (1979). Temporal pattern of division in the dinoflagellate genus Ceratium and its application to the determination of growth rate. J. exp. mar. Biol. Ecol. 39: 1-24

Wright, R. T., Coffin, R. B. (1984). Ecological significance of biomass and activity measurements: Factors affecting bacterioplankton density and productivity in salt marsh estuaries. In: Klug, M. J., Reddy, C. A. (ed.) Current perspectives in microbial ecology. Proc. 3rd. Int. Symp. on Microbial Ecology. Am. Soc. Microbiol., Washington, D.C., p. $485-494$ 